\title{
コナダニ類の繁殖条件の研究
}

I. ケナガコナダ二の繁殖と湿度及び水分含量の関係について1)

\section{Studies on the environmental factors for the breeding of grain mites. Part 1. The effects of humidity and moisture contents on the breeding of Tyrophagus dimidiatus}

\author{
松本克彦2) \\ Katsuhiko Matsumoto
}

\section{まえがき}

ケナガコナダニ Tyrophagus dimidiatus(Hermann, 1804）は無気門德目 Sarcoptiformes のコナダニ科 Acaridae（=Tyroglyphidae）に属するダニで，食品や薬品 などに繁殖するコナダニ類のらち，わが国では最も普通 の種類である．最近にも本種が七味とうがらしなどに繁 殖することが一般の問題となつているし，また人体の排 泄物（尿，糞，喀痰など）に検出されて人体内ダ二症の 病原と目された報告も多い。

コナダニ類の繁殖条件については，これまでにもいく つかの報告があるが，な打未知の分野がはなはだ多い．

しかも，食品，薬品などに㧍けるコナダニ類の発生を防 ぐためには，まずその繁殖条件をあら河る面から明らか にすることが必要である。コナダニ類が繁殖するために は, 少くも温度, 水分, 栄養の 3 条件が好適でなければ ならないと考えられる，今回はまずケナガコナダニを材 料とし, 以上の 3 条件のらち, 温度と栄養をほぼ至適条 件に一定にして，環境湿度ないし食物中の水分含量上繁 殖状況の関係を検討した。

\section{実験方法}

\section{1. コナダニの検出法}

ケナガコナダニの検出法としては従来専らワイルドマ ン法が使用されて来たが，今回は Sasa et al. (1961) の報告した飽和食塩水を用いる方法をひろく活用した。 以下雨法について簡単に述へる。

ワイルドマン法

1）本研究就交部省科学研究費の補助を受けた。

2) 東京女子医科大学笴生虫学教室（主任 白坂竜曠助 教授）

Department of Parasitology, Tokyo Women's Medical College

研究指導 東京大学伝染病研究所 佐々学教授
（1）試料をワイルドマンフラスコにとり，水（必要 により少量の塩酸を加える) をフラスコ全容量の $1 / 3$ 加 え惹沸, あと冷却する。

（2）少量のガソリンを加えよくかきまぜ，30分間放 置する.

（3）水をフラスコの首の所まで追加し完全に両液が 層をなすまで放置する。

（4）ゴム栓を引き上げて頸部を閉じ，上層のガソリ ン部を吸引濾過する。

（5）濾紙上の異物を検鏡する.

原理：ダニの外皮はガソリンによくなじむので，ガソ リン滴に包まれて浮上する。

飽和食塩水法

（1）小三角コルベン $(30 \mathrm{ml})$ 内汇試料 $(0.5 \mathrm{~g}-1.0 \mathrm{~g})$ をとり，少量の中性洗剤溶液 $(0.2 \%)$ を加えて，よく かきまぜる。

（2）小三角コルベンの半量まで飽和食塩水を加えて よく振盪したうえで, さらに飽和食塩水をコルベンの口 まで追加し，10分間放置する。

（3）実体顕微鏡を用い液の表面に浮いたダニを直接 検鏡する。

原理：ダ二の体は食塩水が浸透しにくいので, 比重に より浮上, 食品に㳉食塩水がしみこむので沈澱する.

この食塩水法の長所はワイルドマン法に比べて操作が 簡単で短時間で判定できる, ダニの生死が判定できる, 卵や幼虫もよく検出し得る，ダ二の回收率がよいという 点である.なおワイルドマン法においては, 試料を煮沸, 塩酸加水分解，アルコール脱脂などの処理ができるので 脂肪分の多い食品を処理する場合に有利である.

\section{2. ケナガコナダニの培寒方法}

ケナガコナダニの培養方法は検体試料の量, 環境湿度 規制等の差により，次の諸方法をとつた．各試料は何れ 
も約 300 匹のケナガコナダニを接種し， $25^{\circ} \mathrm{C}$ の恒温室 におかれた。

（1）試料が少量で環境湿度を規制する場合

試料が $5 \mathrm{~g}$ 以下の場合, 試料を小コップにとり, 環境 湿度を調整するために飽和塩類溶液を大コップに入れて 図示（図 1a）のように小コップをその中に入れ上部を ポリエチレンで密封し外部と遮断した.

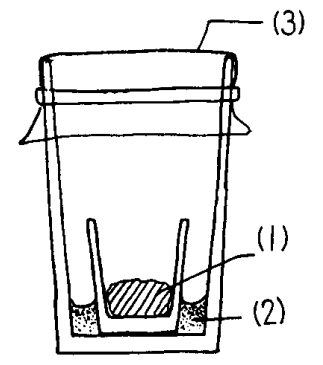

(a)

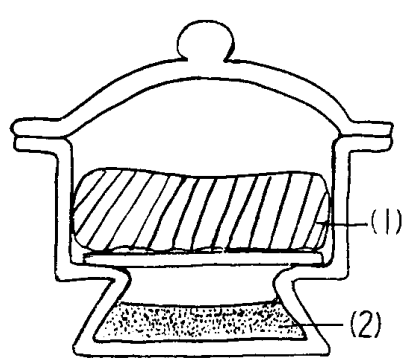

(C)

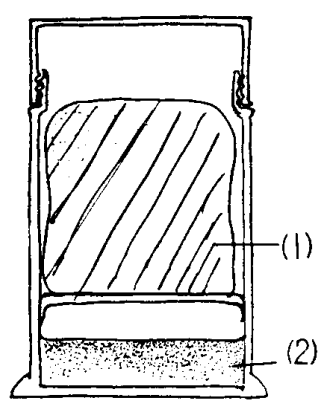

(b)
(b)及びC) 試料5g以上の場合

(1)試料 (2)飽和塩類溶液 (3)ホリエチレン

図 1 ケナガコナダニ培湌方法

（2）試料が大量で環境湿度を規制する場合

試料が $5 \mathrm{~g}$ 以上の時は，図（図 $1 \mathrm{~b} ， \mathrm{c}$ ) のようにデシ ケータ，またはネジ蓋付きのプラスチック容器を用い た。容器の下部に環境湿度調整のための飽和塩類溶液を 入れ，上部に試料およびケナガコナダニを入れた。

（3）環境湿度を規制しない場合

試料をポリエチレン袋にケナガコナダニレ共に密封し た.

\section{実 験 結果}

\section{A. はじめの食物中の水分含量を一定にして環境湿度}

\section{を変えた場合}

\section{1. 粉末飼料}

試料を粉末飼料 $2 \mathrm{~g}$ とし，環境湿度は $95 \% \mathrm{RH}$ (水)， $77 \% \mathrm{RH}\left(\mathrm{NaNO}_{3}\right), 70 \% \mathrm{RH}(\mathrm{NaCl}), 53 \% \mathrm{RH}\left(\mathrm{CaCl}_{2}\right)$, $46 \% \mathrm{RH}\left(\mathrm{K}_{2} \mathrm{CO}_{3}\right) ， 38 \% \mathrm{RH}$ (シリカゲル) に規制した。 環境湿度の計測はミニマ鋭感湿度部によつた。ダ二の繁 殖数はワイルドマン法により集計した.

実験開始後 7 日，20日，48日は這出しダ二数で繁殖状 況を観察したが，48日後は全試料 $2 \mathrm{~g}$ 中の繁殖ダ二数を 観察した（表 1).

表 1 環境湿度とケナガコナダニ繁殖状況の関係

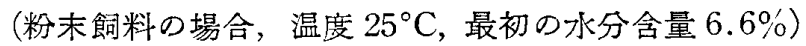

\begin{tabular}{|c|c|c|c|c|c|}
\hline \multirow{2}{*}{$\begin{array}{l}\text { 使用塩類 } \\
\text { 飽和溶液 }\end{array}$} & \multirow{2}{*}{$\begin{array}{c}\text { 湿度 } \\
\% \\
\%\end{array}$} & \multicolumn{3}{|c|}{ 這い出しダ二数 } & \multirow{2}{*}{$\begin{array}{c}\text { 試料 } 2 \mathrm{~g} \text { 中 } \\
\text { の }=\text { 数 } \\
48 \text { 日 }\end{array}$} \\
\hline & & 7 日 & 20 日 & 48 日 & \\
\hline 水 & 95 & 14 & 1,490 & 13,120 & 3,885 \\
\hline $\mathrm{NaNO}_{3}$ & 77 & 26 & 34 & 13,440 & 2,515 \\
\hline $\mathrm{NaCl}$ & 70 & 17 & 23 & 8,660 & 1,950 \\
\hline $\mathrm{CaCl}_{2}$ & 53 & 27 & 30 & 35 & 7 \\
\hline $\mathrm{K}_{2} \mathrm{CO}_{3}$ & 46 & 5 & 11 & 7 & 3 \\
\hline シリカゲル & 38 & 1 & 0 & 1 & 3 \\
\hline
\end{tabular}

実験開始後 7 日では，環境湿度 $38 \% \mathrm{RH}$ （シリカゲ ル）の検体の這出し個体数は 1 で最低であつたが，他の 検体では顕著な差はなかつた．20日後では環境湿度95\% $\mathrm{RH}$ (水) の検体の這出しダ二数 1,490 で一番よく, 湿 度 $77 \% \mathrm{RH} \quad\left(\mathrm{NaNO}_{3}\right), 70 \% \mathrm{RH}(\mathrm{NaCl}), 53 \% \mathrm{RH}\left(\mathrm{CaCl}_{2}\right)$ の這出しダ二数は各々 $34,23,30$ と変化なく, 湿度 45 $\% \mathrm{RH}\left(\mathrm{K}_{2} \mathrm{CO}_{3}\right)$ では這出しダニ数 11 となり，やや減 少している。シリカダルを入れた検体では這出し個体は 0であつた.

48 日後の 這出しダ二数は 環境湿度 $95 \% \mathrm{RH} ， 77 \%$ $\mathrm{RH}$ の検体がよく, 各 $13,120,13,440$ で, 湿度 70 $\% \mathrm{RH}$ のものでも 8,660 であつた，湿度 $53 \% \mathrm{RH}$ では 這出しダ二数 35 で 20 日後のもの之変化なく, 湿度 $46 \%$ $\mathrm{RH}$ でも 7 で変化がなかつた. 48 日後の検体 $2 \mathrm{~g}$ 中の繁 殖ダ二数は環境湿度の低下に従、減少し，湿度 $95 \% \mathrm{RH}$ が最高で 3,885 であつた。 なお 48 日後での試料中のダ 二数は這出しダニ数の傾向と一致した.

\section{2. 七味とうがらし}

検体試料として七味とうがらし $1 \mathrm{~g}$ を使用した。環境 湿度は水㧍よび $\mathrm{NaNO}_{3}, \mathrm{NaCl}, \mathrm{K}_{2} \mathrm{CO}_{3}$ の各飽和溶液上 シリカゲルを使つて各々 $95 \% \mathrm{RH}, 77 \% \mathrm{RH}, 70 \% \mathrm{RH}$, $46 \%$ RH，38\% RH に調整した.

実験開始後 7 日および 20 日ではシリカダルを加えた ものを除いては，這出しダ二数 10-20匹程度で変化な く, シリカゲル群では這出しダ二数 1 および 0 であつた (表2).

48 日後で注湿度 $95 \% \mathrm{RH}$ で這出しダ二数 2,360 で最 高であり, 次いで湿度 $77 \% \mathrm{RH}$ が良く, 這出しダ二数 273 であつた. 這出しダニ数は以下順に $70 \% \mathrm{RH}$ で 57 ， $46 \% \mathrm{RH}$ で $41,38 \% \mathrm{RH}$ で 5 であつた， 48 日後の検 体 $1 \mathrm{~g}$ 中のダ二数は $95 \% \mathrm{RH}$ で 3,538 で最高であり， 以下湿度の低下寸るに従、減少した. 48日後の検体中繁 殖ダニ数と 48 日後の這出しダニ数の傾向は一致した.

3. 米 
表 2 環境湿度とケナガコナダ二繁殖状況の関係 （七味とらがらしの場合, 温度 $25^{\circ} \mathrm{C}$, 最初の水分含量 $6.6 \%$ )

\begin{tabular}{|c|c|c|c|c|c|}
\hline \multirow{2}{*}{$\begin{array}{l}\text { 使用塩類 } \\
\text { 飽和溶液 }\end{array}$} & \multirow{2}{*}{$\begin{array}{c}\text { 湿度 } \\
\% \\
\%\end{array}$} & \multicolumn{3}{|c|}{ 這い出しダ二数 } & \multirow{2}{*}{$\begin{array}{c}\text { 試料lg中 } \\
\text { のダ二数 } \\
48 \text { 日 }\end{array}$} \\
\hline & & 7 日 & 20 日 & 48 日 & \\
\hline 水 & 95 & 3 & 16 & 2,360 & 3,538 \\
\hline $\mathrm{NaNO}_{3}$ & 77 & 18 & 21 & 273 & 134 \\
\hline $\mathrm{NaCl}$ & 70 & 11 & 22 & 57 & 74 \\
\hline $\mathrm{K}_{2} \mathrm{CO}_{3}$ & 46 & 13 & 20 & 41 & 16 \\
\hline シリカゲル & 38 & 1 & 0 & 5 & 13 \\
\hline
\end{tabular}

試料として白米、八分米, 五分米, 玄米の 4 種類の精 白米 $200 \mathrm{~g}$ 使用乙た。環境湿度は $98 \%$ RH (水), 90 $\% \mathrm{RH}\left(\mathrm{KNO}_{3}\right), 85 \% \mathrm{RH}(\mathrm{KCl}), 73 \% \mathrm{RH}(\mathrm{NaCl})$, $56 \% \mathrm{RH}\left(\mathrm{K}_{2} \mathrm{CO}_{3}\right)$ に各々規制した。繁殖状沉法各精白 米 $1 \mathrm{~g}$ に繁殖したダ二数を食塩水法で観察した，実験開 始前の試料の水分含量汁白米 $15.8 \%$ ， 八分米 $15.8 \%$, 王分米 $15.0 \%$ ，䒚米 $15.0 \%$ であつた，結果は表3に表
わした。

実験開始後 14 日では各精白米を通じて環境湿度 $73 \%$ RH，56\% RH が繁殖状況良好であり，玄米は一般に繁 殖不良であつた。14日徭の各精白米の水分含量において 著明なる変化は見られなかつた，29 日後では白米，八 分米，五分米で環境湿度 $85 \%$ RH および $73 \% \mathrm{RH}$ が繁 殖良好で，去米で注さらに高湿度の $98 \%$ - $85 \% \mathrm{RH}$ が 良かつた. 42 日後白米，八分米，五分米で環境湿度 85 -75\% RH のものが繁殖良好で，特に八分米の環境湿 度 $85 \%$ RH で汶コナダ二繁殖 605 で最高であつた. 玄 米では高湿度のものの方が繁殖率が良い傾向にあった。

環境湿度 $56 \%$ RH 中の各精白米の繁殖状態は非常に悪 ふつ沈，米の水分含量注高湿度においた白米に少差がみ られる程度で著明な変化はなかつた。70 日後では繁殖 数は非常に多くなり，特に五分米は最高で環境湿度 $90 \%$ $\mathrm{RH}$ で多二数 $1,194,85 \% \mathrm{RH}$ で $1,158,73 \% \mathrm{RH}$ で 860 で两った。環境湿度 $56 \%$ RH ではさらに悪くなり 繁殖数 0 のものでてき(五分米一環境湿度 $56 \% \mathrm{RH}$ )。 䒺米で注高湿度のものが繁殖良好で，環境湿度 $98 \% \mathrm{RH}$

表 3 環境湿度とケナガコナダ二繁殖状況の䦔俰

(米の場合, 温度 $25^{\circ} \mathrm{C}$, 各ダ二数は米 $1 \mathrm{~g}$ につき)

\begin{tabular}{|c|c|c|c|c|c|c|c|c|c|c|}
\hline \multirow{2}{*}{ 米 } & \multirow{2}{*}{ 鈁 } & \multirow{2}{*}{$\begin{array}{l}\text { 使用塩類 } \\
\text { 飽和溶液 }\end{array}$} & \multirow{2}{*}{$\begin{array}{c}\text { 湿 度 } \\
\%\end{array}$} & \multicolumn{2}{|l|}{14} & \multirow{2}{*}{$\begin{array}{ll}29 & \text { 日 } \\
\text { ダ二数 }\end{array}$} & \multirow{2}{*}{$\begin{array}{c}42 \\
\text { ダ=数 }\end{array}$} & \multirow{2}{*}{ 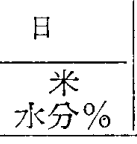 } & \multirow{2}{*}{$\frac{70}{\text { ダ=数 }}$} & \multirow{2}{*}{ 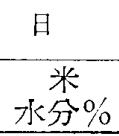 } \\
\hline & & & & ダ二数 & $\begin{array}{l}\text { 米 } \\
\text { 水分\% }\end{array}$ & & & & & \\
\hline \multirow{5}{*}{ 白 米 } & \multirow{5}{*}{ (水分含量 $15.8 \%$ ) } & 水 & 98 & 7 & 14.0 & 22 & 48 & 16.5 & 398 & 17.2 \\
\hline & & $\mathrm{KNO}_{3}$ & 90 & 17 & 14.3 & 5 & 16 & 16.0 & 258 & 14.8 \\
\hline & & $\mathrm{KCl}$ & 85 & 8 & 14.8 & 105 & 127 & 14.1 & 744 & 14.0 \\
\hline & & $\mathrm{NaCl}$ & 73 & 10 & 15.0 & 68 & 200 & 14.4 & 124 & 15.0 \\
\hline & & $\mathrm{K}_{2} \mathrm{CO}_{3}$ & 56 & 25 & 13.6 & 91 & 2 & 14.1 & 4 & 15.0 \\
\hline \multirow{5}{*}{ 八分米 } & \multirow{5}{*}{ （水分含量 $15.8 \%$ ) } & 水 & 98 & 10 & 14.1 & 72 & 61 & 15.5 & 356 & 16.0 \\
\hline & & $\mathrm{LNO}_{3}$ & 90 & 3 & 14.7 & 26 & 7 & 14.0 & 390 & 14.4 \\
\hline & & $\mathrm{KCl}$ & 85 & 8 & 14.7 & 215 & 605 & 14.1 & 331 & 14.0 \\
\hline & & $\mathrm{NaCl}$ & 73 & 42 & 15.6 & 90 & 433 & 14.6 & 104 & 14.4 \\
\hline & & $\mathrm{K}_{2} \mathrm{CO}_{3}$ & 56 & 28 & 13.4 & 11 & 1 & 13.4 & 1 & 12.8 \\
\hline \multirow{5}{*}{ 五分米 } & \multirow{5}{*}{ （水分含量 $15.0 \%$ ) } & 水 & 98 & 15 & 14.4 & 84 & 17 & 24.2 & 0 & 16.0 \\
\hline & & $\mathrm{KNO}_{3}$ & 90 & 8 & 14.0 & 12 & 45 & 15.3 & 1,194 & 17.0 \\
\hline & & $\mathrm{KCl}$ & 85 & 17 & 14.4 & 31 & 108 & 13.8 & 1,158 & 14.4 \\
\hline & & $\mathrm{NaCl}$ & 73 & 20 & 15.3 & 120 & 371 & 15.0 & 860 & 12.4 \\
\hline & & $\mathrm{K}_{2} \mathrm{CO}_{3}$ & 56 & 31 & 14.8 & 33 & 4 & 14.1 & 0 & 12.4 \\
\hline \multirow{5}{*}{ 玄 米 } & \multirow{5}{*}{ （水分含量 $15.0 \%$ ） } & 水 & 98 & 2 & 15.4 & 171 & 23 & 14.0 & 102 & 16.0 \\
\hline & & $\mathrm{KNO}_{3}$ & 90 & 9 & 13.8 & 48 & 10 & 13.9 & 9 & 13.2 \\
\hline & & $\mathrm{KCl}$ & 85 & 6 & 14.2 & 71 & 25 & 14.6 & 23 & 14.8 \\
\hline & & $\mathrm{NaCl}$ & 73 & 8 & 15.0 & 126 & 17 & 14.5 & 11 & 14.4 \\
\hline & & $\mathrm{K}_{2} \mathrm{CO}_{3}$ & 56 & 7 & 14.2 & 16 & 1 & 13.4 & 9 & 12.6 \\
\hline
\end{tabular}


表 4 環境湿度とケナガコナダニ繁殖の関係

（けずりぶしの場合，温度 $25^{\circ} \mathrm{C}$ ，最初の水分含量 $12.3 \%$ ）各ダニ数は“けずりぶし” $1 \mathrm{~g}$ につき）

\begin{tabular}{|c|c|c|c|c|c|c|c|c|}
\hline \multirow{2}{*}{$\begin{array}{l}\text { 使用塩類 } \\
\text { 飽和溶液 }\end{array}$} & \multirow{2}{*}{$\begin{array}{c}\text { 湿 度 } \\
\%\end{array}$} & \multicolumn{2}{|l|}{14} & \multicolumn{2}{|c|}{28 日 } & \multirow{2}{*}{42 日 } & \multicolumn{2}{|c|}{56} \\
\hline & & ダ二数 & 水分含量 & ダ=数 & 水分含量 & & ダ二数 & 水分含量 \\
\hline 水 & 98 & 37 & $33.6 \%$ & 30 & $48.4 \%$ & 24 & 0 & $44.0 \%$ \\
\hline $\mathrm{KNO}_{3}$ & 96 & 22 & 28.6 & 1,350 & 29.4 & 112 & 4 & 29.2 \\
\hline $\mathrm{KCl}$ & 85 & 6 & 16.0 & 1,271 & 21.0 & 1,178 & 31 & 20.4 \\
\hline $\mathrm{NaCl}$ & 73 & 8 & 14.0 & 120 & 12.6 & 86 & 38 & 16.0 \\
\hline $\mathrm{K}_{2} \mathrm{CO}_{3}$ & 56 & 2 & 9.4 & 10 & 7.2 & 24 & 6 & 9.2 \\
\hline
\end{tabular}

食塩水浮游法による

でダニ数 102 であつた. 他の米の高湿度のものもよく繁 殖した．水分含量は高湿度においたものが70日以後あた りから影響を見せ始めた．以上の結果から見るとケナガ コナダニにとつては環境湿度 85-75\% RH におかれた 八分米，五分米が至適条件であると思われる．環境湿度 $56 \%$ RH ではケナガコナダニは余り繁殖できなかつた。

\section{4.けげりぶし}

前項では試料の水分含量が外部の環境湿度によつて影 響され難い物質について検討したが，本項においては水 分含量が環境湿度にもつとも影響され易いけずりぶしに ついて検討した．試料はけずりぶしを $25 \mathrm{~g}$ 使用し，環境 湿度は $98 \% \mathrm{RH}$ (水)， $96 \% \mathrm{RH}\left(\mathrm{KNO}_{3}\right), 85 \% \mathrm{RH}$ $(\mathrm{KCl}), 73 \% \mathrm{RH}(\mathrm{NaCl}), 56 \% \mathrm{RH}\left(\mathrm{K}_{2} \mathrm{CO}_{3}\right)$, の 5 種 類であつた．実験開始時のけずりぶしの水分含量は 12.3 \%であつた。

表 4 はけずりぶしの環境湿度別のケナガコナダニの繁 殖状況である.

実験開始後 14 日での最高繁殖数は環境湿度 $98 \% \mathrm{RH}$ のけずりぶしで $1 \mathrm{~g}$ 中 37 匹であつたけけずりぶしの水 分含量忹環境湿度 $98 \% \mathrm{RH}$ で $33.6 \%, 96 \% \mathrm{RH}$ で 28.6 $\%, 85 \% \mathrm{RH}$ で $16.0 \%, 73 \% \mathrm{RH}$ で $14.0 \%, 56 \% \mathrm{RH}$ で $9.4 \%$ であつた。環境湿度 $56 \% \mathrm{RH}$ のけずりぶしは 実験開始時のものより乾燥しているが他のものは湿めつ ているかまたは同じ状態であつた。

実験開始 28 日後での最高繁殖数は環境湿度 $96 \% \mathrm{RH}$

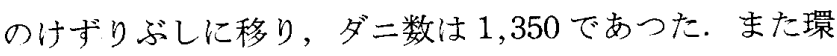
境湿度 $85 \% \mathrm{RH}$ でもダ二数 1,271 であつた。このさい のけずりぶしの水分含量は環境湿度 $96 \%$ RH で $29.4 \%$, $85 \%$ RH で $21.0 \%$ となつた.

42 日後ではコナダニの 最高繁殖数はさらに環境湿度 85\% RH のけずりぶしに移り 1,178匹であつた.

56 日後ではコナダ二繁殖数は急激に減少し，環境湿 度 $73 \%$ RH のけずりぶしの繁殖数 38 で最高であつた. なお，環境湿度 $85 \% \mathrm{RH}$ のけずりぶしの繁殖数は 31 で あった。
環境湿度 $85 \% \mathrm{RH}$ および $73 \% \mathrm{RH}$ のけずりぶしの水 分含量は各々 $20.4 \%, 16.0 \%$ と大体平衡状態となつた。

図 2 環境湿度とケナガコナダ二繁殖状況の関係

(けずりぶしの場合, $25^{\circ} \mathrm{C}$ )

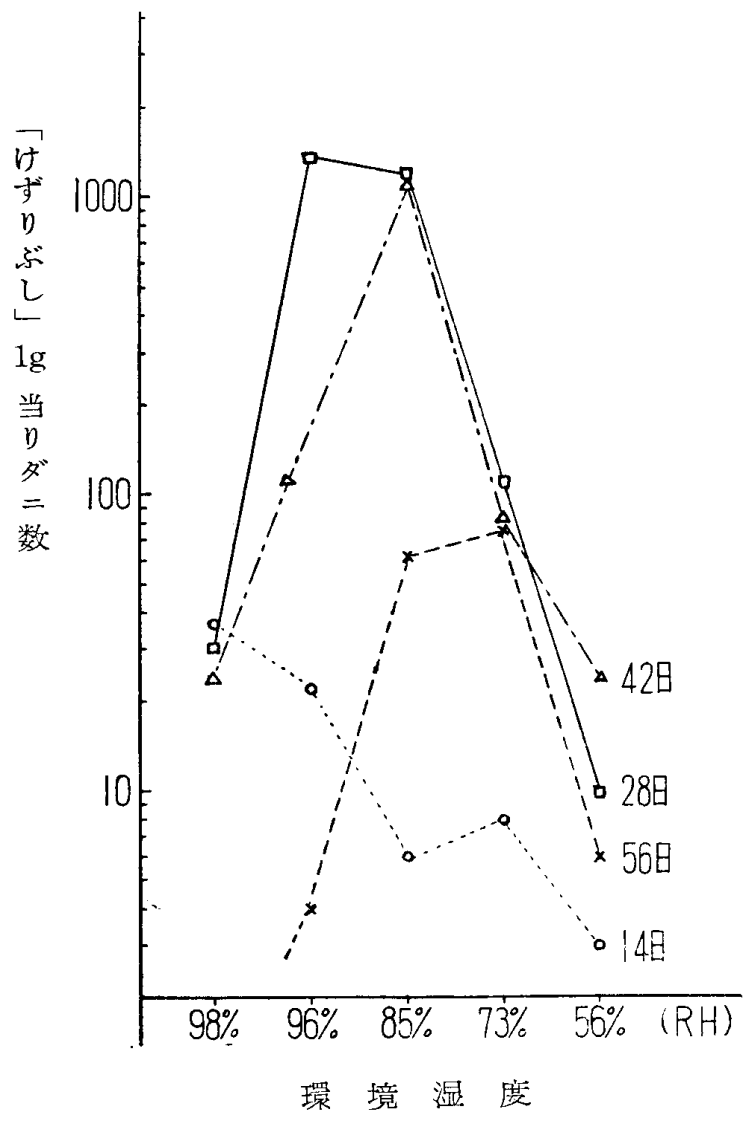

図 2 は以上の結果をまとめたものである. 最高繁殖数 の山が日数を経るに従い 環境湿度の低い方向に移動し た. 環境湿度 $98 \% \mathrm{RH}$ では日数の経過に従い繁殖数は減 少するが，環境湿度 $96 \%$ RH のけずりぶしでは 28 日後 が最高で 42 日後には減少し始好. 環境湿度 $85 \% \mathrm{RH}$ では 42 日後ではまだ 28 日後の繁殖数々同程度である が，56日後では減少する．環境湿度 $73 \% \mathrm{RH}$ のけずり ぶしも前と同じ傾向にあるが，繁殖数は少ない，乾燥状 態にあるものでは水分含量が徐々に上昇して行くにつれ 
てダニの繁殖数も徐々に増加して行く。これら各時期の 最高繁殖数字示すけずりぶしの水分含量は $20-30 \%$ で あり特に $20 \%$ が良かつた。

\section{B. 環境湿度を一定にして水分含量をかえた場合}

試料の水分含量を一定にしておいて各試料を環境湿度 の異る場所においた場合のケナガコナダニの繁殖状況に ついては前記の通りであるが，そのさい環境湿度によつ て試料の水分含量が影響を受けて，さらにその水分含量 がコナダ二の繁殖状洗に密接な関係を有するごとくに見 えたささらにその関連性を確かるるべく，環境湿度を一 定または密封して，試料の水分含量がどのようにケナガ コナダ二の繁殖状況に影響を与えるかを検討した。

\section{1. 粉末飼料}

粉末飼料 $5 \mathrm{~g}$ 検体とし，それに一定量の水を加え， よくかきまぜて水分含量を調整した，結果は表 5 に示し た.

実験開始後 1 力月の這出しダ二数の観察は飼料に水 $0.5 \mathrm{ml}$ を添加し, 水分含量 $17.7 \%$ に調整した検体が最高 で，水添加量 0 のもがそれに次いだ．検体 $1 \mathrm{~g}$ 中の繁 殖ダ二数の最高は這出しダニ数最高の飼料と同じ水分含 量 $17.7 \%$ のもので，6,820 匹であつた。それに次いでダ 二数の多かつたもの注，水分含量 $22.2 \%$ 飼料で 3,900 匹であつた，他の飼料のダ二数は大体低かつた。

表 5 試料水分含㻎とケナガコナダニ繁殖の関係 (粉末飼料 $(5 \mathrm{~g})$ の場合，温度 $25^{\circ} \mathrm{C}$ )

\begin{tabular}{|c|c|c|c|c|c|}
\hline \multirow{2}{*}{$\begin{array}{l}\text { 試 料 } 5 \mathrm{~g} \\
\text { 中水添加 } \\
\text { 量 }\end{array}$} & \multirow{2}{*}{$\mid \begin{array}{c}\text { 水分含量 } \\
\%\end{array}$} & \multicolumn{2}{|c|}{1 力 月 } & \multicolumn{2}{|c|}{2 力月 } \\
\hline & & 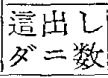 & $\begin{array}{l}\text { 柃体 } 1 \mathrm{~g} \\
\text { 中多二数 }\end{array}$ & $\begin{array}{l}\text { 這出し } \\
\text { 出二数 }\end{array}$ & $\begin{array}{l}\text { 検体 } 1 \mathrm{~g} \\
\text { 中ダ=数 }\end{array}$ \\
\hline $\begin{array}{ll}0 & \mathrm{ml}\end{array}$ & 6.6 & 67 & 7 & 151 & 4,320 \\
\hline 0.5 & 17.7 & 273 & 6,820 & 628 & 10,392 \\
\hline 1.0 & 22.2 & 3 & 3,900 & 179 & 1,824 \\
\hline 2.0 & 33.3 & 2 & 23 & 225 & 250 \\
\hline 3.0 & 41.6 & 3 & 21 & 125 & 27 \\
\hline 4.0 & 48.1 & 5 & 31 & 11 & （全部死 \\
\hline
\end{tabular}

ワイルドマン法による

実験開始後 2 力月の繁殖ダ二数最高はやはり這出し個 体数, 検体 $1 \mathrm{~g}$ 中ダ二数とも水分含量 $17.7 \%$ もので各 々 $628,10,392$ であつた. 水分含量 $6.6 \%$ の飼料で $1 \mathrm{~g}$ 中のダ二数は 4,320 , 水分含量 $22.2 \%$ もので 1,824 で あつた．水分含量 $48.1 \%$ 飼料は 2 力月後で検体にはカ ビが生じコナダニは全部死亡していた。

\section{2. 乾燥酵母殽}

各一定量の水を加え水分含量を変えた乾燥酵母剤 $1 \mathrm{~g}$ を検体として使用した．対照として水無添加のものとシ リカゲルを加えたものの 2 種類を使用した．結果は表 6
に示した．数值はエビオス $1 \mathrm{~g}$ 中心 1 力月後に繁殖せる ダニ数である.食塩水浮游法によりダニ数およびその生 死を判定した。

表 6 試料水分含量とケナガコナダ二繁殖状況の関係 (乾燥酵母剂( $1 \mathrm{~g})$ の場合， I 月月後の試料 $1 \mathrm{~g}$ 中のダ二数, 温度 $25^{\circ} \mathrm{C}$ )

\begin{tabular}{|c|c|c|c|c|c|c|c|}
\hline \multirow{2}{*}{$\begin{array}{l}\text { 試 料 } 1 \mathrm{~g} \\
\text { 中水添加 } \\
\text { 量 }\end{array}$} & \multirow{2}{*}{$\begin{array}{c}\text { 水分 } \\
\text { 含量 } \\
\%\end{array}$} & \multicolumn{3}{|c|}{ A } & \multicolumn{3}{|c|}{ B } \\
\hline & & $\begin{array}{l}\text { ダ= } \\
\text { 総数 }\end{array}$ & $\mid \begin{array}{l}\text { 死騯 } \\
\text { 数 }\end{array}$ & $\begin{array}{c}\text { 死亡摔 } \\
\%\end{array}$ & $\begin{array}{c}\text { 名二 } \\
\text { 総数 }\end{array}$ & $\begin{array}{l}\text { 死駭 } \\
\text { 数 }\end{array}$ & $\begin{array}{c}\text { 死亡率 } \\
\%\end{array}$ \\
\hline 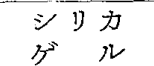 & 4.4 & 98 & 66 & 67.3 & 108 & 68 & 64.1 \\
\hline $0 \mathrm{ml}$ & 4.4 & 144 & 52 & 36.1 & 178 & 48 & 27.0 \\
\hline 0.5 & 7.2 & 172 & 52 & 30.1 & 198 & 42 & 21.2 \\
\hline 1.0 & 8.3 & 204 & 36 & 17.6 & 186 & 32 & 17.3 \\
\hline 1.5 & 12.2 & 242 & 34 & 14.0 & 230 & 32 & 13.9 \\
\hline 2.0 & 14.0 & 2,748 & \begin{tabular}{|l|}
3 \\
\end{tabular} & 7.8 & 1,540 & 118 & 7.7 \\
\hline 3.0 & 16.6 & 15,830 & 770 & 4.6 & 6,550 & 108 & 1.7 \\
\hline 6.0 & 27.2 & 366 & 138 & 37.7 & 76 & 24 & 31.6 \\
\hline
\end{tabular}

食塩水浮游法による

A，B２回の実験をおこなつたが両者ともダ二繁殖数

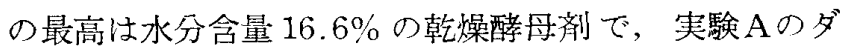
二数 15,830 , 実験 Bでは 6,550 で何れも 死亡率は最低 であつた，水分含量 $27.2 \%$ 試料ではダ二数は， A, B 共各々 366，76 で減少し，逆に死亡率は $30 \%$ 以上に増 加した.コナダニの繁殖数は死亡率と密接な関倸があり 逆比例の傾问にある。な㧍，シリカゲルを加えたものは 繁殖が覀く，ダ二総数は， A， B 各々 $98 ， 108$ と最低で 死亡率は $67.3 \% ， 64.1 \%$ と何れも最高であつた。

\section{C. 初めの食品中の水分合量および環境湿度を変えた} 場合

\section{1. 乾燥醛母剂}

試料は乾燥酵母剂 $2 \mathrm{~g}$ に一定量の水を加え，各 $4.3 \%$ $8.0 \%, 9.8 \%, 14.2 \%, 18.8 \%, 25.2 \%, 31.5 \%$ の水分 含箸に調整した．各水分を含んだ酵母剂各々環境湿度 $100 \% \mathrm{RH}$ (水)，77\% RH $\left(\mathrm{NaNO}_{3}\right), 75 \% \mathrm{RH}(\mathrm{NaCl})$, $43 \% \mathrm{RH}\left(\mathrm{K}_{2} \mathrm{CO}_{3}\right)$ におき，ケナガコナダニの繁殖状況を 観案した。結果は表 7 に示した。数值は食塩水法で観 察した酵母郕 $500 \mathrm{mg}$ 中に繁殖したダ二数を示す。

実験第 2 週では比較的水分含量の低い醳母殽中の繁殖 ダ二数は環境湿度 $100 \% \mathrm{RH}$ の高湿度が良く，特に水分 含量 $4.3 \%$ の酵母剂は湿度 $100 \%$ RH でダ二数 1,995 で あつたが他の湿度では 0 であつた，水分含量 $14.2 \%$ にな

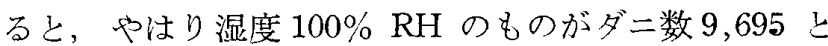
最高になつたが，他の低い湿度 $77 \% \mathrm{RH}$ および $75 \%$ $\mathrm{RH}$ でもダニ数は各々，485，500 と增して来ている. 水分含量が高く $18.8 \%$ 以上の酵母剂になると湿度 $77 \%$ -75\% RH がよく，とくに水分含量 $31.5 \%$, 湿度 $77 \%$ 
$\mathrm{RH}$ の酵母剂でダニ数が 3,865 ，湿度 $75 \%$ RH になる こ 5,265 となつた。高水分含量, 高湿度条件の酵母剂で はダ二繁殖は不良であつた。

表 7 試料水分含量及び環境湿度とケナガニナダニ 繁殖状況口関係

（乾燥酵母斉川の場合，温度 $25^{\circ} \mathrm{C}$, 数值は

$500 \mathrm{mg}$ 中のダ二数)

\begin{tabular}{|c|c|c|c|c|c|}
\hline \multirow{2}{*}{$\begin{array}{c}\text { 水分 } \\
\text { 含量 } \\
\% \\
\end{array}$} & \multirow{2}{*}{$\begin{array}{c}\text { 観察 } \\
\text { 日数 } \\
\text { 週 }\end{array}$} & \multicolumn{2}{|c|}{ 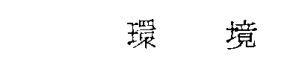 } & \multicolumn{2}{|c|}{ 度 } \\
\hline & & $\begin{array}{c}100 \% \\
\text { (水) }\end{array}$ & $\begin{array}{c}77 \% \\
\left(\mathrm{NaNO}_{3}\right)\end{array}$ & $\begin{array}{c}75 \% \\
(\mathrm{NaCl}) \\
\end{array}$ & $\left(\begin{array}{c}43 \% \\
\left(\mathrm{~K}_{2} \mathrm{CO}_{3}\right)\end{array}\right.$ \\
\hline \multirow{4}{*}{4.3} & 2 & 1,995 & 0 & 0 & 0 \\
\hline & 4 & 5 & 28 & 1,601 & 0 \\
\hline & 6 & 5 & 360 & 12,400 & 0 \\
\hline & 10 & 0 & 2,270 & 89,400 & 0 \\
\hline \multirow{4}{*}{8.0} & 2 & 1,065 & 15 & 0 & 0 \\
\hline & 4 & 3 & 0 & 128 & 5 \\
\hline & 6 & 0 & 705 & 4,885 & 0 \\
\hline & 10 & 0 & 4,000 & 75,000 & 0 \\
\hline \multirow{4}{*}{9.8} & 2 & 4,410 & 20 & 60 & 0 \\
\hline & 4 & 0 & 5 & 4,140 & 5 \\
\hline & 6 & 0 & 545 & 7,725 & 5 \\
\hline & 10 & 0 & 6,900 & 52,000 & 0 \\
\hline \multirow{4}{*}{14.2} & 2 & 9,695 & 485 & 500 & 0 \\
\hline & 4 & 0 & 420 & 1,054 & 15 \\
\hline & 6 & 0 & 8,175 & 5,000 & 0 \\
\hline & 10 & 0 & 33,100 & 77,600 & 0 \\
\hline \multirow{4}{*}{18.8} & 2 & 7,500 & 625 & 1,605 & 65 \\
\hline & 4 & 0 & 890 & 11,728 & 8 \\
\hline & 6 & 0 & 3,585 & 35,450 & 0 \\
\hline & 10 & 0 & 28,000 & 58,400 & 0 \\
\hline \multirow{4}{*}{25.2} & 2 & 5 & 620 & 6,930 & 10 \\
\hline & 4 & 3 & 2,483 & 9,363 & 5 \\
\hline & 6 & 0 & 18,000 & 27,925 & 0 \\
\hline & 10 & 0 & 64,600 & 64,600 & 0 \\
\hline \multirow{4}{*}{31.5} & 2 & 0 & 3,865 & 5,265 & 50 \\
\hline & 4 & 0 & 3,018 & 4,880 & 0 \\
\hline & 6 & 0 & 20,675 & 2,555 & 0 \\
\hline & 10 & 0 & 85,400 & 60,000 & 0 \\
\hline
\end{tabular}

食塩水浮游法による

第 4 週になる上湿度 $100 \%$ RH においた酵母剂は何れ もダ二数が減少または死隇した。湿度 $77 \%$ RH，75\% $\mathrm{RH}$ の酵母剂が何れもダ二の繁殖状況良好となつた。し かし，水分含量 $4.3 \% ， 8.0 \%$ の酵母剤の繁殖状況は余 り良くないが，水分含量 $18.8 \%$ では非常に良くなつて 来た。
第 6 週になると, さらにその傾向は強まり, 水分含量 $18.8 \%$ ，環境湿度 $75 \%$ RH の 酵母剂の 繁殖ダ二数が 35,450 匹で最高となつた。一方，水分含量 $4.3 \%$ の酵母 剤でも湿度 $75 \%$ RH でダ二数が 12,400 で良く繁殖して 来ている。他方水分含量の高い $25.2 \%, 31.5 \%$ の酵母 剤でも湿度 77-75\% RH で繁殖がよくなつてきた。

第 10 週で汉水分含量の多少に拘わらず，湿度 $77 \%$ RH， $75 \%$ RH で繁殖状況は一般的によくなつて来てい る. 水分含量 $4.3 \%$ ，湿度 $75 \% \mathrm{RH}$ の酵母剂の繁殖ダニ

表 8 試料水分含量攻び環境湿度とケナガコナダニ 繁殖状況の関俰

(コナミルクの場合，温度 $25^{\circ} \mathrm{C}$, 数值は $500 \mathrm{mg}$ 中のダ二数)

\begin{tabular}{|c|c|c|c|c|c|}
\hline \multirow{2}{*}{$\begin{array}{c}\text { 水分 } \\
\text { 含量 } \\
\% \\
\end{array}$} & \multirow{2}{*}{$\begin{array}{c}\text { 観察 } \\
\text { 日数 } \\
\text { 週 }\end{array}$} & \multicolumn{2}{|r|}{ 環 境 } & \multicolumn{2}{|c|}{ 度 } \\
\hline & & $\begin{array}{c}100 \% \\
\text { (水) }\end{array}$ & $\begin{array}{c}77 \% \\
\left(\mathrm{NaNO}_{3}\right)\end{array}$ & $\begin{array}{c}75 \% \\
(\mathrm{NaCl}) \\
\end{array}$ & $\begin{array}{c}43 \% \\
\left(\mathrm{~K}_{2} \mathrm{CO}_{3}\right)\end{array}$ \\
\hline \multirow{4}{*}{4.1} & 2 & 501 & 0 & 0 & 0 \\
\hline & 4 & 60 & 398 & 127 & 0 \\
\hline & 6 & 768 & 6,825 & 14,800 & 0 \\
\hline & 10 & 55 & 16,800 & 16,800 & 0 \\
\hline \multirow{4}{*}{6.1} & 2 & 4 & 0 & 0 & 0 \\
\hline & 4 & 0 & 79 & 84 & 0 \\
\hline & 6 & 146 & 14,500 & 28,350 & 0 \\
\hline & 10 & 132 & 12,600 & 18,400 & 0 \\
\hline \multirow{4}{*}{8.8} & 2 & 2 & 1 & 5 & 0 \\
\hline & 4 & 0 & 82 & 22 & 0 \\
\hline & 6 & 0 & 20,900 & 25,500 & 0 \\
\hline & 10 & 0 & 2,800 & 11,600 & 0 \\
\hline \multirow{4}{*}{11.0} & 2 & 20 & 51 & 68 & 1 \\
\hline & 4 & 5 & 450 & 9,519 & 0 \\
\hline & 6 & 355 & 15,100 & 36,250 & 0 \\
\hline & 10 & 660 & 31,200 & 54,200 & 0 \\
\hline \multirow{4}{*}{14.5} & 2 & 215 & 498 & 653 & 0 \\
\hline & 4 & 55 & 10,731 & 23,615 & 0 \\
\hline & 6 & 10 & 35,100 & 96,000 & 0 \\
\hline & 10 & 0 & 30,600 & 79,200 & 0 \\
\hline \multirow{4}{*}{16.5} & 2 & 26 & 76 & 119 & 0 \\
\hline & 4 & 345 & 4,181 & 5,874 & 0 \\
\hline & 6 & 30 & 100,000 & 89,600 & 0 \\
\hline & 10 & 0 & 304 & 18,400 & 0 \\
\hline \multirow{4}{*}{32.2} & 2 & 12 & 34 & 69 & 1 \\
\hline & 4 & 62 & 7,999 & 3,556 & 0 \\
\hline & 6 & 693 & 102,400 & 50,600 & 0 \\
\hline & 10 & 70 & 18,200 & 49,400 & 0 \\
\hline
\end{tabular}

食塩水浮游法による 
数は 89,400 , 水分含量 $31.5 \%$ ，湿度 $77 \% \mathrm{RH}$ の酵母剂 でもダ二数 85,400 となり，ダ二の繁殖数が水分含量で なく環境湿度に影響されるようになつた。

低湿度状態 $(43 \% \mathrm{RH})$ に㧍かれた酵母剂はダ二繁殖 数が非常に少く，水分を沢山含んでいる酵母殽で早い期 にややダニが繁殖する程度であつた。

\section{2. コナミルク}

前出の酵母剤の代りにコナミルクを用い，同様の実験 を行つた. 結果は表 8 に示した。数值はコナミルク 500 $\mathrm{mg}$ 中のダ二数を食塩水浮遊法により観察したものであ る.

実験第 2 週では低水分含量 $(4.1 \%)$ ，高湿度 $(100 \%$ RH）のコナミルクでダ二の繁殖良好で，ダ二数 501 で あつた。他では水分含量 $14.5 \%$, 湿度 $75 \%$ のコナミル クの繁殖数が良く653であつた.

第 4 週では高湿度においたコナミルクの繁殖状況は不 良であつたが，環境湿度 $77 \%$ RH，75\% RH のコナミル クで水分含量の高いものがコナダニの繁殖良好となつ た. とくに，水分含量 $14.5 \%$ ，湿度 $75 \% \mathrm{RH}$ のコナミ ルクでコナダニ数 23,615 となつた.

第 6 週では水分含量の多少に関係なく環境湿度 $77 \%$

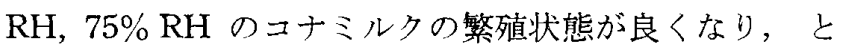

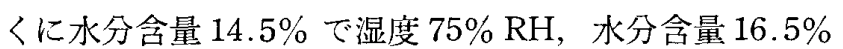
で湿度 $77 \%$ および $75 \% \mathrm{RH}$ または水分含量 $32.2 \%$ で湿 度 $77 \% \mathrm{RH}$ のコナミルクがそれぞれ繁殖状況良好であ つた.

第10週ではコナダ二繁殖数は第 6 週の繁殖数より減少 したがその傾向は同じで，湿度 $77 \%$ RH および $75 \%$ RH のコナミルクが水分含量にかかわりなく一般に良好 であつた。

低湿度 $(43 \% \mathrm{RH})$ においたコナミルクは水分含量に 関係なくいずれも繁殖しなかつた。

\section{3. スキムミルク}

乾燥酵母剂，コナミルクと同様にスキムミルク $2 \mathrm{~g}$ を 試料として実験を行つた。結果は表 9 に示した。数值は 食塩水浮游法によるスキムミルタ $500 \mathrm{mg}$ 中に繁殖した ダ二数である。

スキムミルクのコナダ二繁殖状況は酵母㓮，コナミル クに比べて非常に悪かつた，水分含量の少ないスキムミ ルクの繁殖数はどの湿度でもまた何れの時期をとつても 悪く，水分含量 $13.6 \%$ の試料あたりから繁殖数が良く なつた。第 2 週では水分含量 $13.6 \%$ ，湿度 $100 \% \mathrm{RH}$ スキムミルクが繁殖良好で，また水分含量 $32.0 \%$ で湿 度 $75 \% \mathrm{RH}$ の試料の繁殖数もよかつた。

第 4 週以後では湿度 $100 \% \mathrm{RH}$ におかれた試料のコナ ダニは減少または死減した。水分含量の低い試料は何れ
表 9 試料水分含量及び環境湿度とケナガコナダニ 繁殖状況の関係

(スキムミルクの場合, 温度 $25^{\circ} \mathrm{C}$, 数值は $500 \mathrm{mg}$ 中のダ二数)

\begin{tabular}{|c|c|c|c|c|c|}
\hline \multirow{2}{*}{$\begin{array}{c}\text { 水分含量 } \\
\% \\
\%\end{array}$} & \multirow{2}{*}{$\mid \begin{array}{c}\text { 観察日数 } \\
\text { 週 }\end{array}$} & \multicolumn{2}{|r|}{ 境 } & 湿 & 度 \\
\hline & & $\begin{array}{c}100 \% \\
\text { (水) }\end{array}$ & $\begin{array}{c}77 \% \\
\left(\mathrm{NaNO}_{3}\right)\end{array}$ & $\begin{array}{c}75 \% \\
(\mathrm{NaCl})\end{array}$ & $\left(\begin{array}{c}43 \% \\
\left(\mathrm{~K}_{2} \mathrm{CO}_{3}\right)\end{array}\right.$ \\
\hline \multirow{4}{*}{5.4} & 2 & 1 & 10 & 5 & 0 \\
\hline & 4 & 0 & 0 & 1 & 0 \\
\hline & 6 & 3 & 0 & 0 & 0 \\
\hline & 10 & 0 & 0 & 0 & 0 \\
\hline \multirow{4}{*}{7.4} & 2 & 2 & 4 & 10 & 0 \\
\hline & 4 & 1 & 0 & 2 & 0 \\
\hline & 6 & 0 & 0 & 0 & 0 \\
\hline & 10 & 0 & 0 & 0 & 0 \\
\hline \multirow{4}{*}{10.5} & 2 & 4 & 18 & 11 & 0 \\
\hline & 4 & 0 & 2 & 6 & 0 \\
\hline & 6 & 1 & 13 & 5 & 0 \\
\hline & 10 & 5 & 70 & 125 & 0 \\
\hline \multirow{4}{*}{13.6} & 2 & 827 & 31 & 5 & 1 \\
\hline & 4 & 33 & 3 & 4 & 3 \\
\hline & 6 & 0 & 149 & 2 & 0 \\
\hline & 10 & 0 & 1,125 & 90 & 0 \\
\hline \multirow{4}{*}{18.2} & 2 & 47 & 24 & 85 & 2 \\
\hline & 4 & 18 & 0 & 21 & 1 \\
\hline & 6 & 0 & 0 & 22 & 0 \\
\hline & 10 & 0 & 95 & 1,260 & 0 \\
\hline \multirow{4}{*}{21.2} & 2 & 205 & 71 & 55 & 0 \\
\hline & 4 & 0 & 0 & 25 & 1 \\
\hline & 6 & 0 & 18 & 25 & 0 \\
\hline & 10 & 0 & 215 & 825 & 15 \\
\hline \multirow{4}{*}{32.0} & 2 & 31 & 578 & 908 & 0 \\
\hline & 4 & 4 & 82 & 600 & 0 \\
\hline & 6 & 0 & 0 & 840 & 0 \\
\hline & 10 & 0 & 5 & 5,750 & 100 \\
\hline
\end{tabular}

食塩水浮游法による

の湿度においたものでも繁殖しないが，10.5\%以上の水 分在含んだ試料では湿度 $77 \% \mathrm{RH} ， 75 \% \mathrm{RH}$ のものが よく繁殖し，とくに水分含量 $32 \%$ ，湿度 $75 \% \mathrm{RH}$ の試 料の繁殖ダ二数は第 10 週で 5,750 となつた。

\section{考察}

コナダニ類は分類学的には Michael, Oudemanns, Vitzthum らにより整理され，さらに Zakhvatkin によ り再検討されて系統発生学的に分類体系がまとめあげら 
れた。

これらコナダニ類は早くから貯藏食品の害虫として注 目され多くの研究が行われている.とくにその被害, 生 態，駆除などについて Solomon $(1943 ， 1944)$ が綜説を かいて，この方面の研究の一助とされている. かくのご とく, 欧米におけるコナダニ類の研究は専ら貯蔵食品の 害虫として農学的立場から重要視されて来ているもので あるが，わが国における研究はむしろ医学的見地からの 報告が山積されている. Miyake et Scriba（1893）は世 界最初に人尿中にダ二在発見し，これが泌尿系症状を起 す病原と考えて以来, 糞便, 尿, 喀痰などにコナダ二類 と推定されるダニを報告する文献が 100 以上も医学者に よつて表わされている.

しかし，病因となるダニそのものの研究は古くは岸 田，杉本の報告が散見されるに過ぎなかつた．最近に至 り貯蔵食品害虫の記載として，コナダニ類の倉庫発生例 についての飯田（1953）の報告がある．また輸入砂糖に ダニが見出されたことなどからコナダニ類の関心も高ま 门), 浅沼 (1948 1950) が貯蔵食品害虫としてのダ二類 の概括的な紹介を行つた。

このように貯藏食品の害虫として，またこれらが人体 内ダ二症を惹起する原因上考えられることからも，コナ ダ二類の有害性は衛生学的見地からも見逃し得ない所で ある。

関谷 (1948) はネダニの生活史に関する実験的研究を 行い， $38^{\circ} \mathrm{C} ， 100 \% \mathrm{RH}$ でネダニが最も早く発育して卵 から成虫になるまでに 9 日を要したことを見ている。浅 沼（1950）はケナガコナダニを $90 \% \mathrm{RH}$ で飼育し， 温度と発育の関係について 報告している，加藤・本間

（1954）は味噌椇内に扔けるサトウダニの集団構造の発 育過程について報告している.

さて，これらコナダニ類の発育には適温が必要である ことは, 経験的にもコナダニの発生が冬少く, 夏に多い ことからも明らかである.Zakhvatkin（1941）の実験に おいても，アシブトコナダニは $90 \% \mathrm{RH}$ で $22^{\circ} \mathrm{C}$ が最 も繁殖率が高いことを見ている．また Tyrophagus noxius では $90 \% \mathrm{RH}$ で $25^{\circ} \mathrm{C}$ が最高繁殖率を示すことを 見ている. 佐々・三浦（1953，佐々1954より）の米, チョコレートを餌としたケナガコナダニ実験では這出し 個体数を見ているが， $24^{\circ} \mathrm{C}$ で $100 \% \mathrm{RH}$ が最も繁殖率 が高く, 関谷 (1948) のネダ二の実験では $27^{\circ} \mathrm{C}, 100 \%$ RH が最適であつた. 飯室 (1956) のケナガニナダニに 関する実験ではチョコレート，チーズ，米などを餌とし ているが，チョコレートでは $25^{\circ} \mathrm{C}$ で $75 \% \mathrm{RH}$ ，チーズ では $25^{\circ} \mathrm{C}$ で $84 \% \mathrm{RH}$, 米では $25^{\circ} \mathrm{C}$ で $100 \% \mathrm{RH}$ が最 適繁殖条件であることを見ている。
本実験では以上の 報告を参考にして一応温度条件を $25^{\circ} \mathrm{C}$ に一定して実験を進めたものである. 表 10 の最適 繁殖条件は本実験に捛けるケナガコナダ二の水分条件に 対する結果をまとめたものである.

表10 各種試料に和けるケナガコナダニ の最適繁殖条件

\begin{tabular}{|c|c|c|c|c|}
\hline 試 & 温 度 & 最初 & $\begin{array}{l}\text { 至適水 } \\
\text { 分含量 }\end{array}$ & $\begin{array}{l}\text { 至適環 } \\
\text { 境湿度 }\end{array}$ \\
\hline 粉 末 飼 料 & $25^{\circ} \mathrm{C}$ & $6.6 \%$ & $-\%$ & $95 \%$ \\
\hline 11 & "1 & 6.6 & 17.7 & - \\
\hline 七味とうがらし & " & 8.0 & - & 95 \\
\hline * & " & 15.0 & 14.1 & $85-75$ \\
\hline けずりぶし & $\prime \prime$ & 12.3 & 21.0 & 85 \\
\hline 乾燥 酵母棛 & " & 4.4 & 16.6 & - \\
\hline
\end{tabular}

温度を一定 $\left(25^{\circ} \mathrm{C}\right)$ にしているが, 環境湿度の至適条件 を見る上材料によりやや異なつて見える。すなわち粉末 飼料掞よび七味とうがらしで摆境湿度 $95 \%$ RH が至 適条件であるが，米とかけずりぶしになると環境湿度の 要求は $85 \sim 75 \% \mathrm{RH}$ と低くなっている. しかし水分含量 の方から見ると，実験開始時の水分含量は各試料により 異つているが，実験開始後の至適水分含量は大体 15-20 \%の間に安定している。このことから環境湿度の要求差 は材料の性質および状態によるものと推察される。すな わち環境湿度 $95 \% \mathrm{RH}$ を要する試料注粉末状であり, また最初の水分含量が比較的低い状態（ケナガコナダニ の繁殖条件に比して）にある. 故にこの低い水分含量を 至適繁殖条件の要求する適当な量まで速やかに引き上げ るために高い環境湿度を要求するものと考えられる。

けずりぶしの場合は試料の水分量が非常に外界の湿度 に影響され易いために比較的低い環境湿度でもよいと思 われる．実験開始時の早い時期では環境湿度 $100 \% \mathrm{RH}$ に扔かれたけずりぶしの方が繁殖数は良いが，日時を経 過するに従い，環境湿度 $100 \%$ RH のものの繁殖状況は 不良となり，試料の水分含量も $30 \%$ 以上となる。ささら に日時を経ると繁殖数の最高は環境湿度 $90 \% \mathrm{RH}$ のけ ずりぶしに移るが，水分含量が $30 \%$ 以上になる上コナ ダニ数法減少する．繁殖最高値はさらに環境湿度の低い $85 \% \mathrm{RH}$ の所に移り，以後は水分含量も一定して来るの で相対的なダ二数は減少するが，その時期の最高繁殖は ほぼ環境湿度 85-75\% RH のけずりぶしに定まる。すな わち環境湿度を横軸としたコナダニの最高繁殖数の移動 は試料の至適水分含量の推移に一致している.

米の場合は比較的水分含量が外界の湿度に影響されに くく一定しているし，また水分含量自身も $15.0 \%$ と他 の試料の場合のコナダニ繁殖の至適水分含量と一致して いるので，環境湿度 85-75\% RH に至適条件が落着いて 
いるものと思わ机る．以上のことから水分条件のうちで ケナガコナダニの繁殖に対して一番制限要因になり得る と思われるものは試料の水分含量であつて，この水分含 量を維持するかまたは々れを必要とするのであり，また その必要に応じて各物質によつて環境湿度要求に違、を 生じて来るもの上考えら礼る。

以上のようにケナガニナダニの繁殖条件のうちの水分 条件には環境湿度だけでなく，その試料の水分含量が重 要な関連性を帯びて来るものである.

そこで実験Cにおいて環境湿度と水分含量を同時に変 えた実験索行い，さらに雨者の関連性について確かめた ものである。乾燥酵母郕、コナミルクの実験では雨者共 実験開始後の早、時期で流試料の水分含量が低く高湿度 のものがよい繁殖率を示しているのは実験 $\mathrm{A} の$ 粉末飼料 とか七味上らがらしの結果上一致している。また水分含 量 $18.8 \%$ ，環境湿度 $75 \%$ RH の試料のコナダ二繁殖率 が高いこ上はここに至適条件があるここを物語つてい る。こ机がさらに日経る汇従い水分含量に関倸なく環 境湿度 $77-75 \%$ RH がコナダ二の繁殖に大、に影響を与. えて来るようになる。恐らく，これはケナガニナダニの 繁殖が最初試料の水分含量に影響されているが，経時的 に試料の水分含量が環境湿度に影響きれ下水分の出入に よつて平衡状態に達するため上思われる。

以上の結果からいえることはケナガニナダニの繁殖に 最適な水分条件泣試料の水分含量が 15-20\% で，環境湿 度は 75\% RH 近辺である。 そして食品の状態によりコ ナダニの繁殖に最適な環境湿度が定まり，さらにその食 品の水分含量によつても或程度環境湿度の変化を要求し 水分含量が至適条件になるとコナダニ本来の至適環境湿 度を䆚求するようになるものと思われる。

Kozulina（1940）はケナガコナダニ，アシブトコナダ 二の卵はそれぞれ $50 \%$ RH，60\% RH 以下では孵化せず 最高の餒化率は各々 $70 \% \mathrm{RH}, 100 \% \mathrm{RH}$ であることを 報告している. Newstead (1918) らはコナダニの繁殖し た殼物の水分含量が 14-18\%で $12.4 \%$ 以下では繁殖しな いことを見ているが，本実験の最適繁殖条件の水分含量 が 15-20\% であることとよく一致している。しかしネダ ニ，ゴミコナダニ類が見出される環境はさらに水分含量 が高い状態にあり，温度、湿度ないし水分に対する適性 は種類により異つているものと思われる。

なお，試料を米とした場合，4種類の精白米を使用し たが，八分米拉よび五分米のコナダ二繁殖成績が良好で 白米および玄米の成績は不良であつた。，米の食害状況を 見ると胚芽の部分を喰い荒しているのが見えた．このこ とから白米の場合には栄盖的な面から糠および肧芽が取 られているのでコナダニの繁殖が悪く，玄米の場合は糠
および胚芽はあるが硬くて喰べにくいというような機械 的な理由が考えられる。

\section{まと め}

ケナガコナダニの繁殖条件のうち, 温度と栄養をほぼ 至適条件として，環境湿度ないし食物中の水分含量上繁 殖状況の関係について検討した。

1. 粉末飼料（水分含量 $6.6 \%$ ），七味とらがらし（水 分含量 $8.8 \%$ ）の上うな粉末状の試料で，水分含量を一 定にし, 環境湿度を変えて, ケナガコナダニの繁殖状況 について調べた，実験開始後 48 日または 53 日では㻴境 湿度 $95 \%$ RH においた試料のコナダ二繁殖状況が最良 であつた。

同じように粉末状態の試料（粉末飼料および乾燥酵母 剤)で環境湿度を一定にして試料の水分含量を変え下コ ナダニの繁殖状況を観察した.コナダ二繁殖の至適水分 含量汢各々 $17.7 \% ， 16.6 \%$ です心。

2. 環境湿度に影響され易いけずりぶしの場合，コナ ダ二の繁殖の至適噮境湿度は高湿度から経時的に移動し て，85-75\% RH に定まつた。このさいのけずりぶしの 水分含量法何れも20 30\% 以内であつた。

8. 米の場合に水分含量が外部の湿度に影響されにく く，15.0\%付近にあるので，コナダ二繁殖の至適環境湿 度は 85-75\% に落着いた，分分搗き米，五分搗き米のコ ナダニ繁殖状況は良好であつたが，白米拉よび立米では 不良であつた。

4. 乾燥酵母剂、コナミルク、スキムミルクの最初の 水分含量を変えて，各々を環境湿度別におき，乙动のケ ナガコナダ二の繁殖状況を観察した．実駼初期には水分 含量が低くて環境湿度の高、試料上，水分含量 $18.8 \%$; 環境湿度 $75 \%$ RH の試料のコナダ二繁殖状況が良好で あつた，時間の経過上共に最初の水分含量に関倸なく， 環境湿度 $75 \%$ RH の試料のコナダ二繁殖が 盛んになっ た.

以上の結果を総合する上，水分含量の少い粉末状の試 料では最初コナダ二繁殖に高湿度を要求するが，次第に 試料の水分含量は環境湿度に影響されて，水分含量が高 くなる上，至適環境湿度は 85-75\% RH となり，このさ いの至適水分含量は 15-20\% であることが分つた．すな わち，ケナガニナダニの各食品における繁殖には食品自 身の水分含量と環境湿度の両者が著しく影響することが 判明した。

本論交の一部要旨は 1961 年 4 月久留米に和ける第 13 回日本衛生動物学会で発表した。

本研究を指導された東大伝染病研究所，佐々学教授， 
実験に協力を得た三浦昭子，武田植人氏らに深謝する。

\section{引用交献}

1）浅沼 靖 (1948)：サトウダニは日本にいたか。新 昆虫, $1(8)$ : 28 . 一2) 浅沼 靖 (1948) : 砂糖ダ二. Sanitation, 1(819)：148-150. - -3) 浅沼 端 (1949)： 食品につくダ二。食品衛生, $1(2): 42-44$. 一4) 浅沼

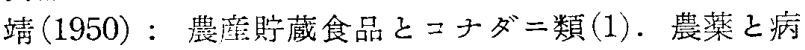
虫, $4(8)$ : 249-253. -5) 浅沼 端 $(1950)$ ：農産眝蔵 食品そコナダ二類 $(2)$. 農薬と病虫, $4(11) ： 374-375$. -6) 飯田鈴吉 (1953)：食料食徎に於けるコナダ二類 の大発生例について。公衆衛生, $(13 / 5) ： 47-49.7)$ 飯室 勇 (1956)：コナダ二類の研究，1，ケナガコナ ダニ Tyrophagus dimidiatus の生態に関する研究. 衛生動物， 7(1)：27-37。－8）加藤・本開(1954)：サ トゥダ二の集団構蕧の発達通程について，日本生態学 雑誌，4(2)：88-93. -9) Kozulina, O. V. (1940)： The effect of humidity and temperature on the development of the eggs of grain mites. Uchen. Zap mosk. gosnd. Uni., No. 42, Zool., 179-184. -10) Miyake et Scriba (1893) : Vorläufige Mitteilung über einen neuen menschlichen Parasiten. Berl. Kl. W. Nr. $16: 374$ - -11) Miyake et Scriba (1893) : Nephrophagus sanguinarius, ein neuer menschlicher Parasit in Urogenitalappart. Mitt. a. d. med. Fak. d. k. Japan Univ. (Tokyo) III. I. -12) Newstead, R. and Duvall, H. M. (1918) : Bionomic, morphological and economic report on the acarids of stored grain and flour. Roy. Soc. Rep. No. 2 of grain pests (War Ctte.), 48pp. 一13)估々学 (1954) 食品 害虫及び衛生害虫としてのニナダ二類. 医家丵書 168, 医学書院, 東京. - - 14) 関谷英夫 (1948) ラ ッキョウのネダニに就いて. 応用昆虫, 4(4)：175184. -15) Solomon, M. E. (1943) : Tyroglyphid mites in stored products 1 . A survey of published information. Supplement 1944. Dept. of Scientific and Industrial Research. London. 7pp. -16) Zakhratkin, A. A. (1941) : Acariens Tyroglyphoides, I' U. S. S. R. 6(1) : (Arachnoidea) in Faune de I' U. S. S. R. $475 p$ p.

\section{Summary}

Experiments were made to observe the effects of environmental humidity and of the moisture contents of various stored food products on the breeding of the grain mite, Tyrophagus dimidiatus. The humidity was regulated by keeping the materials in glass vials containing saturated solutions of various salts, such as $\mathrm{K}_{2} \mathrm{CO}_{3}\left(46 \%\right.$ R.H.), $\mathrm{CaCl}_{2}$ (53\% R.H.), $\mathrm{NaCl}\left(70 \%\right.$ R.H. ), $\mathrm{NaNO}_{3}$ (77\% R.H.) and of water $(95 \%$ R.H. $)$. All experiments were made at $25^{\circ} \mathrm{C}$.

Using powdered materials as the food for the mites and relatively low moisture contents, such as laboratory animal food $(6.6 \%$ water content), shichimipepper $(8.8 \%)$ or dried yeast $(4.4 \%)$, breeding of the mites shows the best condition at the highest humidity of $95 \%$ R.H. With the dried and sliced fishmeal (kezuribushi), which water content rapidly balances with the relative humidity of the environment, the best breeding of the mites were seen at 85 to $75 \%$ R.H. In the case of rice which contained $15.0 \%$ of water, less effects of the relative humidiy were seen both on the growth of the mites and on changes of water contents.

Water contents of the materiais to be tested were also found to affect the breeding of the mites. Both in powdered laboratory animal food in dried yeast, the optimum water content for the growth of the mites was seen at $17.7 \%$ and $16.6 \%$ respectively, and their breeding seemed to be interfered as it became either lower or higher from the level.

By using dried yeast, powder milk and skim milk as the material, experiments were designed to observe the speed of breedings of the mites in the food containing different grades of water contents and kept at different relative humidities. In the initial few weeks, the best breeding was seen in lots with low moisture contents and kept at high relative humidities as well as in those with $18.0 \%$ water content and kept at $75 \%$ R.H. In the later stages after several weeks, the highest mite counts were seen in those kept at $75 \%$ R.H. indifferent from the initial water contents of the foods.

Although their relative effects seem to differ greatly by the nature of the food to be tested, through these experiments, it has been demonstrated that both relative humidity of the environment and the moisture content of the materials are the essential factors for the breeding of the mites. For the purpose of preventing the stored food products and some drugs from breeding of the mites, either dessication of the materials or the storage at low humidity was found to be the effective measure. 